\title{
Peripartum responses of dairy cows to prepartal feeding level and dietary fatty acid source
}

\author{
A. Hayirli, ${ }^{\star}$ D. H. Keisler, $†$ and L. Doepelł ${ }^{1,2}$ \\ *Department of Animal Nutrition and Nutritional Disorders, Faculty of Veterinary Medicine, Atatürk University, Erzurum 25700, Turkey \\ †Department of Animal Sciences, University of Missouri, Columbia 65211 \\ ‡Department of Agricultural, Food and Nutritional Science, University of Alberta, Edmonton, AB, Canada, T6G 2P5
}

\section{ABSTRACT}

This experiment was conducted to investigate the effect of feeding level and oilseed supplementation during the close-up dry period on energy balance (EB), hepatic lipidosis, metabolic status, and productivity in early lactation. Seventy-seven Holstein cows were blocked according to parity and expected calving date and then assigned randomly to 1 of 6 treatments in a 2 $\times 3$ factorial allocation with 2 feeding levels: ad libitum $(\mathrm{AL})$ or $30 \%$ feed restriction (FR), and 3 dietary fatty acid sources: canola seed, linola seed, or flaxseed at $8 \%$ of dietary dry matter (DM), to enrich the rations with oleic, linoleic, or linolenic acids, respectively during the last $4 \mathrm{wk}$ of gestation. After parturition, all cows were fed a common lactation diet. Cows fed AL lost less body weight $(-2.9$ vs. $-6.0 \%)$ and body condition score $(+0.67$ vs. $-2.30 \%)$, and consequently were in more positive $\mathrm{EB}(+4.6$ vs. $-0.3 \mathrm{Mcal})$ during the prepartum period than cows subjected to FR. Postpartum, FR cows lost less body weight ( -9.7 vs. $-12.4 \%)$ and experienced less severe negative EB ( -4.5 vs. -7.0 Mcal) than AL cows. Cows fed AL had higher plasma insulin (6.8 vs. $4.4 \mu \mathrm{IU} / \mathrm{mL}$ ) and lower nonesterified fatty acid concentrations (436 vs. $570 \mathrm{mEq} / \mathrm{mL}$ ) during the close-up period than cows subjected to FR. Cows fed AL tended to have lower liver glycogen content in early lactation than cows subjected to FR (4.4 vs. 2.9 $\mu \mathrm{g} / \mathrm{g}$ of DM), but had similar triglyceride content (13.1 $\pm 1.2 \mu \mathrm{g} / \mathrm{g}$ of DM). Fatty acid source did not influence response variables. In conclusion, eliminating intake depression by FR during the close-up period had positive carryover effects on EB and metabolic status during early lactation, but feeding linoleic and linolenic acids via unprotected oilseeds only had negligible effects on peripartum responses.

Received August 2, 2010.

Accepted October 21, 2010.

${ }^{1}$ Corresponding author: ldoepel@ucalgary.ca

${ }^{2}$ Current address: University of Calgary, Faculty of Veterinary Medicine, 3280 Hospital Drive NW, Calgary, AB, Canada T2N 4Z6.
Key words: prepartum feeding level, prepartum fatty acid source, transition period, hepatic lipidosis

\section{INTRODUCTION}

The transition from gestation to lactation is accompanied by a complex series of hormonal changes and is the most metabolically challenging time for the dairy cow (Drackley, 1999). Depending upon animal and dietary factors as well as environmental and management factors, DMI can decrease by up to $40 \%$ as cows approach parturition (Hayirli et al., 2003) and increases at a slower rate than milk yield does during early lactation (Doepel et al., 2002). Dairy cows thus lose BW and body condition (BC), and consequently experience negative energy balance (EB) in early lactation (Grummer et al., 2004). Negative EB is one of the triggering factors for the development of peripartum health problems (Drackley, 1999) and is metabolically reflected by decreases in blood insulin, glucose, and IGF-1 concentrations and hepatic glycogen (GLY) content and increases in blood NEFA, BHBA, and growth hormone concentrations and hepatic triglyceride (TG) content (Vazquez-Añon et al., 1994).

The severity of hepatic lipidosis immediately after parturition is correlated negatively with DMI before parturition (Grummer, 1995). The elevation in blood NEFA concentration as parturition approaches is also associated with the decline in prepartum DMI (Vazquez-Añon et al., 1994). Thus, earlier nutritional strategies have focused on minimizing the elevation in blood NEFA concentration by increasing energy and DM intakes (Drackley, 1999; Doepel et al., 2002). However, feeding high energy diets does not necessarily eliminate negative EB and hepatic lipidosis at parturition and in the early postpartum period because feeding these diets has been associated with greater declines in DMI precalving (Coppock et al., 1972). Indeed, the severity of negative EB and hepatic lipidosis appears to be linked more to the degree of depression in DMI before parturition rather than to the total intake of DM or energy during the close-up dry period (Mashek 
and Grummer, 2003b). Agenäs et al. (2003) reported that cows fed restricted amounts of DM during the dry period increased their postpartum DMI and milk yield at faster rates and experienced less severe negative EB than cows fed ad libitum (AL). These cows also had lower NEFA concentrations during early lactation (Holtenius et al., 2003).

The ruminant liver normally deposits very small amounts of fat. However, when cows are in negative EB fat accumulates in the liver due to excessive hepatic uptake of NEFA mobilized from adipose tissue, inability of the liver to sufficiently dispose of fatty acids (FA) via oxidation, and inability of the liver to export TG as very low density lipoproteins (Grummer, 1993). Controlling hepatic lipidosis therefore depends on limiting lipolysis from adipose tissue, limiting NEFA uptake by the liver, increasing oxidation of FA in the liver, or increasing export of TG from the liver, or a combination of these (Grummer, 1993). Recent studies have focused on the role of polyunsaturated fatty acids (PUFA) in suppressing reesterification of FA into TG in the liver. In a series of in vitro studies (Mashek et al., 2002; Mashek and Grummer, 2003a,b), it was demonstrated that liver slices incubated in media supplemented with linoleic and linolenic acids had a reduced capacity for esterification of palmitic and stearic acids into TG, suggesting that PUFA may have the potential to limit fat accumulation in the liver. However, in vivo studies dealing with hepatic metabolism in transition cows fed PUFA are limited.

It was hypothesized that prepartal feed restriction (FR) would alleviate negative EB and hepatic lipidosis by eliminating DMI depression and that dietary essential PUFA enrichment would modify hepatic lipid metabolism by reducing FA esterification. Thus, the objective of this experiment was to examine the effects of prepartum feeding level (FL) and dietary fatty acid source (FAS) on lactation performance, metabolic profile, and hepatic lipid accumulation.

\section{MATERIALS AND METHODS}

\section{Animals, Management, and Diets}

Eighty-nine dry Holstein cows at the University of Alberta Dairy Research and Technology Centre were blocked according to parity and expected calving date and used from $34 \mathrm{~d}$ before projected calving until 63 DIM. Twelve cows were subsequently excluded from the experiment due to very early calving $(\mathrm{n}=3)$, twinning $(\mathrm{n}=3)$, severe mastitis $(\mathrm{n}=1)$, not pregnant $(\mathrm{n}=1)$, sluggish appetite prepartum $(\mathrm{n}=1)$, and death caused by septic shock following liver biopsy $(\mathrm{n}=3)$. Thus, the experiment was conducted using 77 dry pregnant
Table 1. Nutrient content of the oilseeds

\begin{tabular}{lccc}
\hline $\begin{array}{l}\text { Nutrient, } \\
\% \text { of DM }\end{array}$ & Canola & Linola & Flax \\
\hline CP & 22.3 & 25.3 & 23.1 \\
NDF & 13.2 & 13.6 & 18.4 \\
ADF & 9.2 & 8.0 & 12.2 \\
Ether extract & 48.4 & 46.9 & 42.9 \\
Calcium & 0.41 & 0.22 & 0.20 \\
Phosphorus & 0.71 & 0.59 & 0.43 \\
Fatty acid & & & \\
Oleic & 51 & 13 & 15 \\
Linoleic & 22 & 72 & 18 \\
Linolenic & 12 & 3 & 56 \\
\hline
\end{tabular}

${ }^{1}$ Expressed as \% of total fatty acid esters.

Holsteins entering first $(\mathrm{n}=29)$, second $(\mathrm{n}=17)$, third $(\mathrm{n}=16)$, fourth $(\mathrm{n}=6)$, and fifth $(\mathrm{n}=9)$ lactations.

The experimental protocol was approved by the University of Alberta Animal Care and Use Committee for Livestock (Edmonton, AB, Canada) and cows were cared for in accordance with the guidelines of the Canadian Council on Animal Care (CCAC, 1993). Animals were housed in a tie-stall barn and milked twice daily at 0400 and $1600 \mathrm{~h}$. They had free access to water throughout the experiment and were allowed to exercise for $2 \mathrm{~h}$ after the a.m. milking.

All cows were fed the standard herd far-off dry diet ad libitum from dry off until d -28 relative to parturition. Cows were then assigned randomly within block to 1 of 6 prepartal treatments in a $2 \times 3$ factorial arrangement of $2 \mathrm{FL}$ and 3 dietary FAS. The prepartal diets were offered $\mathrm{AL}(\mathrm{n}=38)$ or at $30 \% \mathrm{FR}(\mathrm{n}=$ 39) until parturition. Feed restriction was based on the average feed intake recorded during the last $4 \mathrm{~d}$ preceding the initiation of treatment. The prepartal diets were formulated to meet the nutrient demands of a $650-\mathrm{kg}$ dry cow (NRC, 2001), and contained 1 of 3 rolled oilseeds: canola $(\mathbf{C}, \mathrm{n}=28)$, linola $(\mathbf{L}, \mathrm{n}=25)$, or flax $(\mathbf{F}, \mathrm{n}=24)$ at $8 \%$ of dietary DM. The nutrient composition of the oilseeds is shown in Table 1 and that of the prepartal diets in Table 2.

After calving, all cows were fed the same lactation diet that did not contain the prepartal oilseeds (Table 2 ). Except for cows in the FR group during the close-up period, all cows during the experimental period were fed to obtain $5 \%$ orts. Both the prepartum and lactation diets were fed as a TMR once daily.

\section{Data Collection, Sampling, and Analytical Procedures}

Feed offered and orts collected were recorded daily. To maintain the formulated DM composition of the diet, silage DM was determined weekly and concentrate DM every other week using a microwave oven. Ingredients 
Table 2. Ingredient and nutrient content of the diets (\% of DM)

\begin{tabular}{|c|c|c|c|c|}
\hline \multirow[b]{2}{*}{ Item } & \multicolumn{3}{|c|}{ Prepartal diet ${ }^{1}$} & \multirow{2}{*}{$\begin{array}{l}\text { Postpartal } \\
\text { diet }\end{array}$} \\
\hline & $\mathrm{C}$ & $\mathrm{L}$ & $\mathrm{F}$ & \\
\hline \multicolumn{5}{|l|}{ Ingredient } \\
\hline Alfalfa silage & - & - & - & 22.00 \\
\hline Barley silage & 50.00 & 50.00 & 50.00 & 25.06 \\
\hline Alfalfa hay & 10.00 & 10.00 & 10.00 & 10.00 \\
\hline Barley grain & 7.27 & 7.27 & 7.27 & 22.34 \\
\hline Canola seed & 8.00 & - & - & \\
\hline Linola seed & - & 8.00 & - & \\
\hline Flaxseed & - & - & 8.00 & - \\
\hline Soybean meal & 5.34 & 5.34 & 5.34 & - \\
\hline Corn grain & - & - & - & 4.32 \\
\hline Corn gluten meal & - & - & - & 6.51 \\
\hline Oat hulls & 17.60 & 17.60 & 17.60 & - \\
\hline Canola meal & - & - & - & 1.07 \\
\hline Fish meal & - & - & - & 1.12 \\
\hline Vegetable oil & - & - & - & 2.04 \\
\hline Calcium soap of fatty acids & - & - & - & 1.94 \\
\hline Molasses & - & - & - & 0.39 \\
\hline $\mathrm{NaHCO}_{3}$ & - & - & - & 0.83 \\
\hline Limestone & - & - & - & 0.63 \\
\hline Mineral-vitamin premix ${ }^{2}$ & 1.79 & 1.79 & 1.79 & 1.75 \\
\hline \multicolumn{5}{|l|}{ Nutrients } \\
\hline $\mathrm{NE}_{\mathrm{L}},{ }^{3} \mathrm{Mcal} / \mathrm{kg}$ & 1.68 & 1.68 & 1.68 & 1.73 \\
\hline $\mathrm{CP}, \%$ & 13.2 & 13.4 & 13.2 & 17.9 \\
\hline NDF, \% & 41.3 & 41.4 & 41.7 & 32.5 \\
\hline $\mathrm{ADF}, \%$ & 25.5 & 25.4 & 25.7 & 21.2 \\
\hline Ether extract & 6.1 & 6.0 & 5.7 & 5.5 \\
\hline $\mathrm{Ca}, \%$ & 0.61 & 0.59 & 0.59 & 1.33 \\
\hline $\mathrm{P}, \%$ & 0.39 & 0.38 & 0.37 & 0.48 \\
\hline
\end{tabular}

and feed refusals were sampled weekly and composited monthly for subsequent analyses. Dry matter content was determined by drying the samples at $55^{\circ} \mathrm{C}$ in a forced air oven for $48 \mathrm{~h}$. Crude protein content was determined using a Leco FP-428 Nitrogen Determinator (Leco Corp., St. Joseph, MI), ADF and NDF using the procedures of Van Soest et al. (1991), and macro minerals according to AOAC (1990). Gas chromatographic analysis of FA of the oilseeds was also determined (Bell et al., 2006).

Cow health status was monitored daily. Cow BW was measured on $\mathrm{d}-34$ relative to calving and $\mathrm{d} 1,14,28$, and 56 postpartum before the a.m. feeding but after blood sampling. On the same days BCS was determined using a 1 to 5 scale with 1 being emaciated and 5 being obese (Edmonson et al., 1989). Energy balance during the periparturient period was calculated as described by Rabelo et al. (2003) with a slight modification that instead of using a fixed calf weight $(40 \mathrm{~kg})$, actual calf weights were used for calculating energy requirement of pregnancy.

Milk production was automatically recorded at each a.m. and p.m. milking. Milk samples were collected weekly on Wednesdays. One aliquot was preserved with 2-bromo-2-nitro-1,3-propandiol for analyses of protein, fat, lactose, and SCC using infrared spectroscopy (MilkoScan 605, Foss Electric, Hillerød, Denmark) at Canwest Central Milk Testing Laboratory (Edmonton, $\mathrm{AB}$, Canada). A second aliquot was frozen at $-20^{\circ} \mathrm{C}$ for determination of FA composition. Briefly, milk fat was extracted using the procedure of Folch et al. (1957) and then esterified by redissolving the fat in chloroform (5 to $10 \mathrm{mg}$ per $50 \mu \mathrm{L}$ of chloroform) and then combining 50 $\mu \mathrm{L}$ of this with $2 \mathrm{~mL}$ of sodium methoxide (methanolic base, Supelco, Bellefonte, PA). The procedures of Bell et al. (2006) were then followed for methylation and determination of FA composition by gas chromatography. Additional milk samples collected on the first and fourth weeks of lactation were analyzed for antioxidant activity using the ferric reducing/antioxidant power (FRAP) assay (Benzie and Strain, 1999).

Blood samples were collected via venipuncture into tubes containing sodium heparin (Vacutainer, Becton Dickinson and Co., Franklin Lakes, NJ) from a coccygeal vessel 1 to $2 \mathrm{~h}$ before feeding on $\mathrm{d}-34,-27$, $-21,-14,-3$, and -1 relative to projected calving 
date. For cows that calved later than expected, blood sampling was continued every other day until calving. After calving, blood samples were obtained on d 1, 3, 7,10 , and 14 and then weekly until d 63 . The samples were centrifuged at $3,300 \times g$ for $15 \mathrm{~min}$ at $4^{\circ} \mathrm{C}$, and plasma was stored at $-20^{\circ} \mathrm{C}$ until enzymatic analyses of glucose (P7119, Sigma-Aldrich, St. Louis, MO) according to the colorimetric assay of Raabo and Terkildsen (1960), NEFA [NEFA-HR(2) kit, Wako Chemicals USA Inc., Richmond, VA] with the modifications of Johnson and Peters (1993), acetate (Enzytec, Scil Diagnostics GmbH, Viernheim, Germany) as described in Doepel and Lapierre (2010), and BHBA (310-A, Sigma) as described by Williamson and Mellanby (1974). Plasma insulin concentration was determined by RIA (Coat-ACount, Diagnostic Products Corp., Los Angeles, CA), and IGF-I was determined as described by Novak et al. (2002) with the following modification: IGF-I used for iodination and the reference standard was GroPep Receptor grade Human IGF-I (GroPep, CU100, GroPep Ltd., Adelaide, SA, Australia). Plasma was also analyzed for leptin (Delavaud et al., 2002) and cholecystokinin (CCK; Bradford et al., 2008). Inter- and intraassay coefficients of variation were 10.6 and $7.1 \%$ for insulin, 11.0 and $8.4 \%$ for IGF-1, 8.2 and $3.5 \%$ for leptin, and 5.2 and $2.6 \%$ for CCK, respectively.

At $1100 \mathrm{~h}$ on $\mathrm{d}-34$ relative to expected calving and on $\mathrm{d} 1$ and 21 postpartum, liver samples were obtained by puncture biopsy (Doepel et al., 2002). The liver tissue was rinsed in saline, frozen in liquid nitrogen, and then stored at $-20^{\circ} \mathrm{C}$ until analyses. Liver lipids were extracted by the method of Folch et al. (1957) and TG content was determined by the modified method of Foster and Dunn (1973). Liver GLY content was measured according to the method described by Lo et al. (1970). Both parameters were expressed as a proportion of dry tissue weight.

\section{Statistical Analysis}

Analysis of covariance was conducted using the MIXED procedure of SAS (SAS Institute, 2002) in an incomplete randomized block design with time as the repeated measure. The first-order autoregressive [ar(1)] covariance structure was used for measurements that were equally spaced such as performance and production variables and the spatial power $[\mathrm{sp}(\mathrm{pow})($ time $)]$ covariance structure was used for measurements that were unequally spaced, such as blood variables (Littell et al., 1996). Pretreatment measurements were used as covariates for the respective response variables. The linear model to test the effects of treatment on response variables was applied separately for the prepartum and postpartum periods. Because there was no FL by FAS interaction effect on any response variables, this interaction term was omitted from the final linear model, which was as follows:

$$
\begin{gathered}
\mathrm{Y}_{\mathrm{ijkl}}=\mu+\mathrm{Cov}+\mathrm{B}_{\mathrm{i}}+\mathrm{FL}_{\mathrm{j}}+\mathrm{FAS}_{\mathrm{k}}+\mathrm{t}_{\mathrm{l}} \\
+(\mathrm{FL} \times \mathrm{t})_{\mathrm{j} 1}+(\mathrm{FAS} \times \mathrm{t})_{\mathrm{kl}}+\mathrm{e}_{\mathrm{ijk} \mathrm{kl}},
\end{gathered}
$$

where $Y_{\mathrm{ijkl}}=$ response variable, $\mu=$ population mean, Cov $=$ covariate, $\mathrm{B}_{\mathrm{i}}=$ block $(\mathrm{i}=1$ to 14$), \mathrm{FL}_{\mathrm{j}}=$ feeding level $(\mathrm{j}=\mathrm{AL}$ and $\mathrm{FR}), \mathrm{FAS}=$ fatty acid source $(\mathrm{k}=$ $\mathrm{C}, \mathrm{L}$, and $\mathrm{F}), \mathrm{t}_{1}=$ time $(\mathrm{l}=\mathrm{d}$ or wk relative to parturition), and $\mathrm{e}=$ residual error $[N(\sigma, \mu ; 0,1)]$.

Cow nested within treatment $[\operatorname{cow}(\mathrm{FL} \times \mathrm{FAS})]$ was the random term and served as the whole-plot error term for all data analyses. Because of unequal replication of the treatments, probabilities of significance were generated using the Satterthwaite approximation (Littell et al., 1996). Moreover, differences among the prepartal FAS were attained using the PDIFF option (SAS Institute, 2002). Probability values $\leq 0.05$ were considered significant, and $0.05<P \leq 0.10$ were considered a tendency. Data are reported as least squares means \pm SEM.

\section{RESULTS}

\section{Health Status and Performance}

Cow health status was not affected by treatment. Neither prepartal FL nor FAS affected the frequency of mastitis $(n=7)$ or metabolic disorders such as parturient paresis $(\mathrm{n}=5)$ and displaced abomasum $(\mathrm{n}=3)$.

During the close-up period, cows in the FR group were subjected to a $30 \%$ feed restriction on an as fedbasis relative to their individual mean intakes recorded during the last $4 \mathrm{~d}$ pre-treatment. However, compared with that in AL cows, the reduction in DMI of the FR cows was only $26 \%$ (Table 3 ). Dry matter intake for cows subjected to AL exponentially decreased as they approached calving, whereas that for cows subjected to FR was nearly constant and decreased only on the last $2 \mathrm{~d}$ of gestation $(\mathrm{FL} \times$ time interaction, $P<0.0001$; Figure 1A). During early lactation, DMI $(\mathrm{kg} / \mathrm{d})$ was not different between the FR and AL cows, but DMI as a percentage of BW was higher for cows subjected to FR than for cows fed AL $(P<0.05)$. Moreover, the rate of increase in DMI $(\mathrm{kg} / \mathrm{d})$ after parturition was greater for FR cows than for AL cows, due primarily to differences during wk 5 and $8(P<0.0001$; Figure $1 \mathrm{~A})$. No effects of prepartal FAS on mean DMI were observed both prepartum and in early lactation. However, cows fed $\mathrm{F}$ during the close-up period experienced less DMI depression toward parturition $(\mathrm{FAS} \times$ time interaction, 
Table 3. Effects of prepartal feeding level on intake and lactation during the periparturient period

\begin{tabular}{|c|c|c|c|c|}
\hline \multirow[b]{2}{*}{ Variable $^{1}$} & \multicolumn{2}{|c|}{ Feeding level $^{2}$} & \multirow[b]{2}{*}{ SEM } & \multirow[b]{2}{*}{$P>F$} \\
\hline & $\mathrm{AL}$ & FR & & \\
\hline \multicolumn{5}{|l|}{ Prepartum } \\
\hline DMI, $\mathrm{kg}^{\mathrm{a}, \mathrm{b}, \mathrm{c}}$ & 12.2 & 9.0 & 0.24 & 0.0001 \\
\hline DMI, $\%$ of $B W^{a, b, c}$ & 1.78 & 1.35 & 0.04 & 0.0001 \\
\hline $\mathrm{EB}, \mathrm{Mcal}^{\mathrm{a}, \mathrm{b}}$ & 4.63 & -0.33 & 0.45 & 0.0001 \\
\hline \multicolumn{5}{|l|}{ Postpartum } \\
\hline DMI, $\mathrm{kg}^{\mathrm{a}, \mathrm{b}, \mathrm{d}}$ & 15.7 & 16.5 & 0.47 & 0.21 \\
\hline DMI, $\%$ of $B W^{a, b, d}$ & 2.64 & 2.84 & 0.08 & 0.05 \\
\hline $\mathrm{EB}, \mathrm{Mcal}^{\mathrm{a}, \mathrm{e}}$ & -6.99 & -4.49 & 0.67 & 0.007 \\
\hline Milk yield, $\mathrm{kg}^{\mathrm{a}, \mathrm{b}, \mathrm{d}}$ & 34.8 & 34.4 & 0.91 & 0.70 \\
\hline FCM yield, $\mathrm{kg}^{\mathrm{a}}$ & 35.2 & 33.7 & 1.00 & 0.27 \\
\hline Fat, $\%^{\mathrm{a}}$ & 4.21 & 3.96 & 0.10 & 0.05 \\
\hline Fat, $\mathrm{kg}^{\mathrm{a}}$ & 1.42 & 1.33 & 0.04 & 0.13 \\
\hline Protein, $\%^{a}$ & 2.84 & 2.88 & 0.03 & 0.26 \\
\hline Protein, $\mathrm{kg}^{\mathrm{a}, \mathrm{c}, \mathrm{f}}$ & 0.97 & 0.98 & 0.03 & 0.85 \\
\hline Lactose, $\%^{\mathrm{a}}$ & 4.49 & 4.49 & 0.03 & 0.98 \\
\hline Lactose, $\mathrm{kg}^{\mathrm{a}, \mathrm{e}}$ & 1.56 & 1.55 & 0.04 & 0.83 \\
\hline $\mathrm{SCC}, 1,000 / \mathrm{mL}^{\mathrm{a}, \mathrm{d}}$ & 340 & 334 & 122 & 0.97 \\
\hline FRAP,$\mu M^{a, e}$ & 239 & 273 & 7 & 0.0008 \\
\hline
\end{tabular}

${ }^{\mathrm{a}}$ Time effect, $0.01<P \leq 0.0001 ;{ }^{\mathrm{b}}$ prepartal feeding level by time interaction effect, $0.01<P<0.0001$; ${ }^{\mathrm{c}}$ prepartal fatty acid source by time interaction effect, $0.01<P \leq 0.05$; ${ }^{\mathrm{d}}$ prepartal fatty acid source by time interaction effect, $0.01<P \leq 0.0001$; ${ }^{\mathrm{e}}$ prepartal fatty acid source by time interaction effect, $0.05<P \leq 0.10$; ${ }^{\mathrm{f}}$ prepartal feeding level by time interaction effect, $0.05<P \leq 0.10$.

${ }^{1}$ Prepartum data cover the last $27 \mathrm{~d}$ of gestation and postpartum data cover the first $63 \mathrm{~d}$ of lactation. $\mathrm{EB}=$ energy balance; $\mathrm{FCM}=0.4 \times$ milk yield $(\mathrm{kg})+15 \times($ milk yield, $\mathrm{kg} \times$ fat, $\% / 100) ; \mathrm{FRAP}=$ ferric reducing/ antioxidant power.

${ }^{2} \mathrm{AL}=$ ad libitum; $\mathrm{FR}=30 \%$ feed restriction.

$P<0.02 ;$ Figure 2B) and had a greater rate of increase in DMI after parturition than cows fed $\mathrm{C}$ and $\mathrm{L}$ during the close-up period (FAS $\times$ time interaction, $P<0.01$; Figure 2B).

No differences in preexperimental BW and BCS were observed across the experimental groups $(682 \pm 81 \mathrm{~kg}$ and $3.36 \pm 0.19$, mean $\pm \mathrm{SD}$; Table 4 ). Cows in the FR group lost BW to a greater extent than did cows in the AL group during the close-up period $(P<0.0007)$. All cows lost BW progressively after parturition (time effect, $P<0.0001$ ). During the first 2 mo postpartum, cows subjected to $\mathrm{FR}$ prepartum lost less BW than cows subjected to AL prepartum $(P<0.05)$. Cows fed $\mathrm{F}$ lost the least BW during the close-up period $(-3.6 \%)$, followed by those fed $\mathrm{L}(-4.1 \%)$ and $\mathrm{C}(-5.7 \% ; P<$ 0.05). However, prepartal FAS did not affect BW during early lactation.

Cows in the $\mathrm{AL}$ group gained $\mathrm{BC}$, whereas those in the FR group lost $\mathrm{BC}$ during the close-up period $(P<$ 0.05; Table 4). All cows also lost BC progressively after parturition (time effect, $P<0.0001$ ). Within the first month of lactation, FR cows tended to lose less BC than AL cows $(P<0.10)$. Prepartal FAS did not affect BCS during the periparturient period.

Cows fed AL remained in positive EB during the entire close-up period whereas those subjected to FR were in negative EB during the last week before calving
$(P<0.0001$; Table 4; Figure 1B). However, the overall numerically negative $\mathrm{EB}$ for $\mathrm{FR}$ cows was not different from zero $(-0.33 \pm 0.45, P<0.47)$. During early lactation, all cows were in negative EB (Figure 1B), which was less severe for FR cows than for AL cows $(P<0.007)$. Prepartal FAS did not affect mean EB either prepartum or in early lactation. After parturition, however, cows previously fed $\mathrm{C}$ tended to overcome negative EB at a faster rate than those previously fed $\mathrm{L}$ and $\mathrm{F}(\mathrm{FAS} \times$ time interaction, $P<0.10$; figure not shown).

\section{Lactation Responses}

Prepartal FL had no effect on milk yield (Figure 2A), and with the exception of milk fat percentage, no effect on milk composition (Table 3 ). Cows subjected to prepartal FR had lower milk fat percentage $(P<0.05)$ in the subsequent lactation than those fed AL. Lactation responses to prepartal FAS were variable. Milk yield was highest for cows previously fed L compared with those previously fed $\mathrm{C}$ and $\mathrm{F}$ (FAS effect, $P<0.007$ and FAS $\times$ time interaction, $P<0.0001$; Figure $2 \mathrm{C}$ ). No main effects of prepartal FAS were found on milk fat, protein, and lactose percentages. However, cows previously fed $\mathrm{L}$ or $\mathrm{F}$ tended to produce greater quantities of milk protein $(P<0.09)$ and lactose $(P<0.10)$ 
A

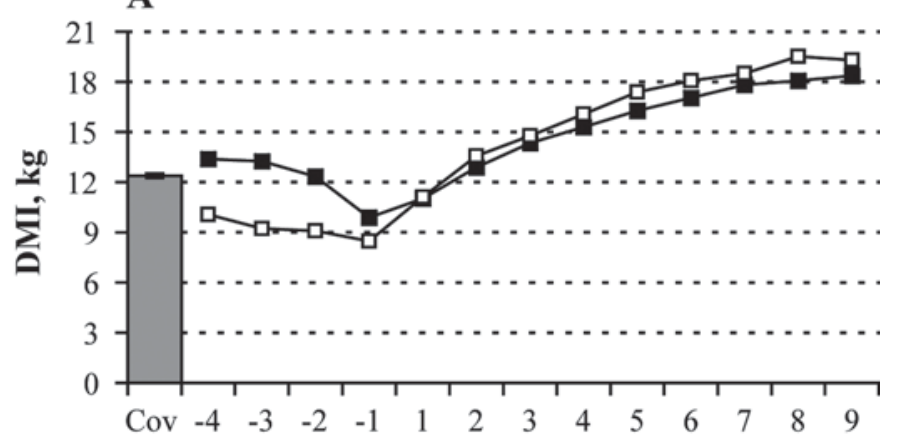

B

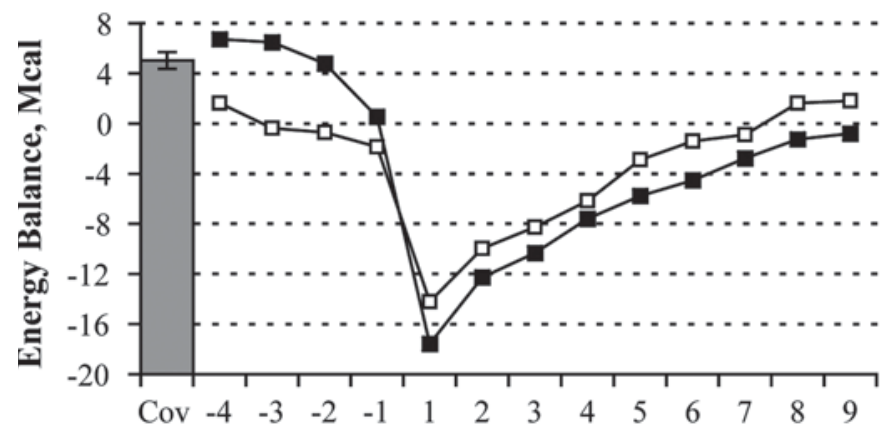

Week Relative to Parturition

Figure 1. Effects of prepartal feeding level $(\mathbf{\square}, \mathrm{AL}=$ ad libitum; $\square$, $\mathrm{FR}=30 \%$ feed restriction) on (A) DMI and (B) energy balance during the periparturient period. Probabilities of significance for effects of prepartal feeding level, time, and prepartal feeding level by time interaction were 0.0001 for all during the prepartum period (SEM = 0.26 ) and $0.21,0.0001$, and 0.0001 during the postpartum period (SEM $=0.49$ ), respectively (panel A). Probabilities of significance for effects of prepartal feeding level, time, and prepartal feeding level by time interaction were 0.0001 for all during the prepartum period (SEM $=$ 0.55 ) and $0.007,0.0001$, and 0.84 during the postpartum period (SEM $=0.94)$, respectively (panel B).

than cows previously fed $\mathrm{C}(\mathrm{FAS} \times$ time interaction, $P<0.004$ for protein yield and $P<0.07$ for lactose yield). The mean milk protein and lactose yields were 1.01 and $1.61 \mathrm{~kg} / \mathrm{d}$ for cows fed L, 1.00 and $1.57 \mathrm{~kg} / \mathrm{d}$ for cows fed F, and 0.92 and $1.48 \mathrm{~kg} / \mathrm{d}$ for cows fed C, respectively.

The effects of prepartal FL and FAS on milk FA composition were minimal. Across treatments, the mean proportion (\% of FA esters; $P>0.10$ ) was 5.28 for $\mathrm{C}_{14: 0}$, 26.22 for $\mathrm{C}_{16: 0}, 1.85$ for $\mathrm{C}_{16: 1-\text { cis }}, 13.50$ for $\mathrm{C}_{18: 0}, 5.17$ for $\mathrm{C}_{18: 1-\text { trans }}, 0.71$ for conjugated linoleic acid (CLA) $)_{18: 2, \mathrm{n}-9,11}$, and 0.01 for $\mathrm{CLA}_{18: 2, \mathrm{n}-10,12}$. The mean ratio of saturated to unsaturated FA was also unaffected by treatment and averaged 52.3:47.7. Cows subjected to FR had lower total $\mathrm{C}_{18: 3}(0.44$ vs. $0.48 \mathrm{~g} / 100 \mathrm{~g}$ of total FA esters; $P<$ 0.02) in milk than those fed AL. Prepartal FAS had no effect on fatty acid composition.
A
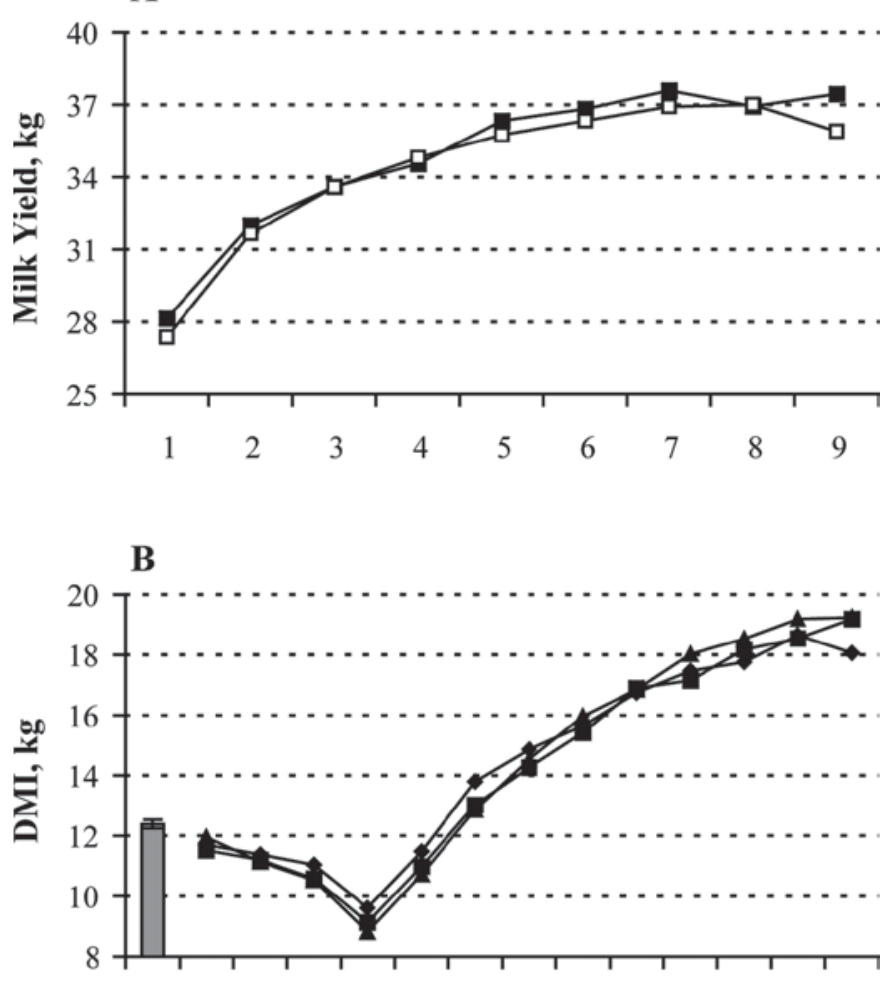

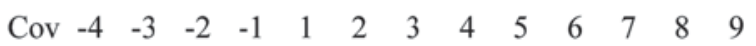

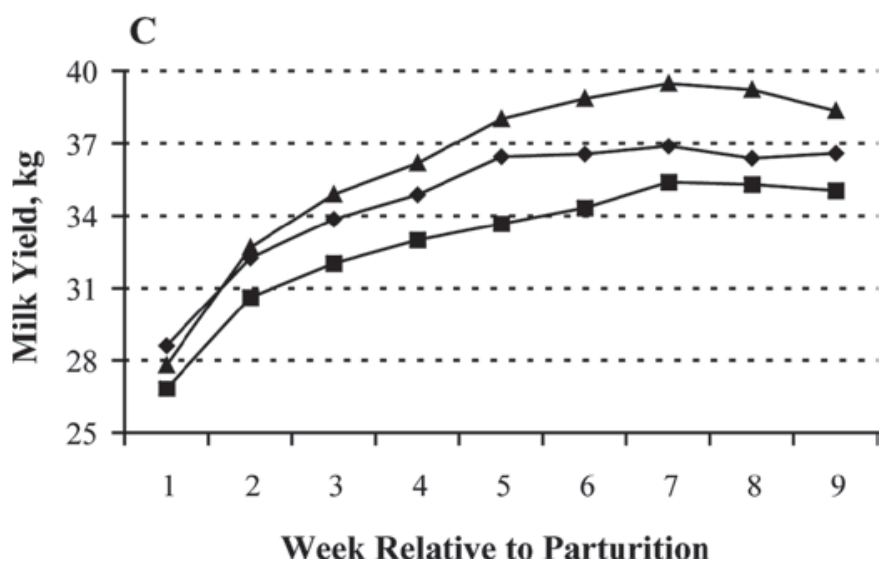

Figure 2. Effects of prepartal feeding level $(\mathbf{\square}, \mathrm{AL}=$ ad libitum; $\square, \mathrm{FR}=30 \%$ feed restriction, panel A) and dietary fatty acid sources at $8 \%$ on a DM basis $(\mathbf{\square}, \mathrm{C}=$ canola seed; $\mathbf{\Delta}, \mathrm{L}=$ linola seed; $\bullet$ $\mathrm{F}$ = flaxseed, panels $\mathrm{B}$ and $\mathrm{C}$ ) on milk yield during early lactation (panels A and C) and DMI during the periparturient period (panel B). Probabilities of significance were $0.70,0.0001$, and 0.007 for effects of prepartal feeding level, time, and prepartal feeding level by time interaction, respectively ( $\mathrm{SEM}=0.93$; panel A). Probabilities of significance for effects of prepartal fatty acid source, time, and prepartal fatty acid source by time interaction were $0.67,0.0001$, and 0.02 during the prepartum period $(\mathrm{SEM}=0.32)$ and $0.94,0.0001$, and 0.01 during the postpartum period $(\mathrm{SEM}=0.59)$, respectively (panel $\mathrm{B})$. Probabilities of significance were $0.007,0.0001$, and 0.0001 for effects of prepartal fatty acid source, time, and prepartal fatty acid source by time interaction, respectively $(\mathrm{SEM}=1.12$; panel $\mathrm{C})$. The $\mathrm{DMI}$ data during the acclimatization period were used as covariate for milk yield analysis. 

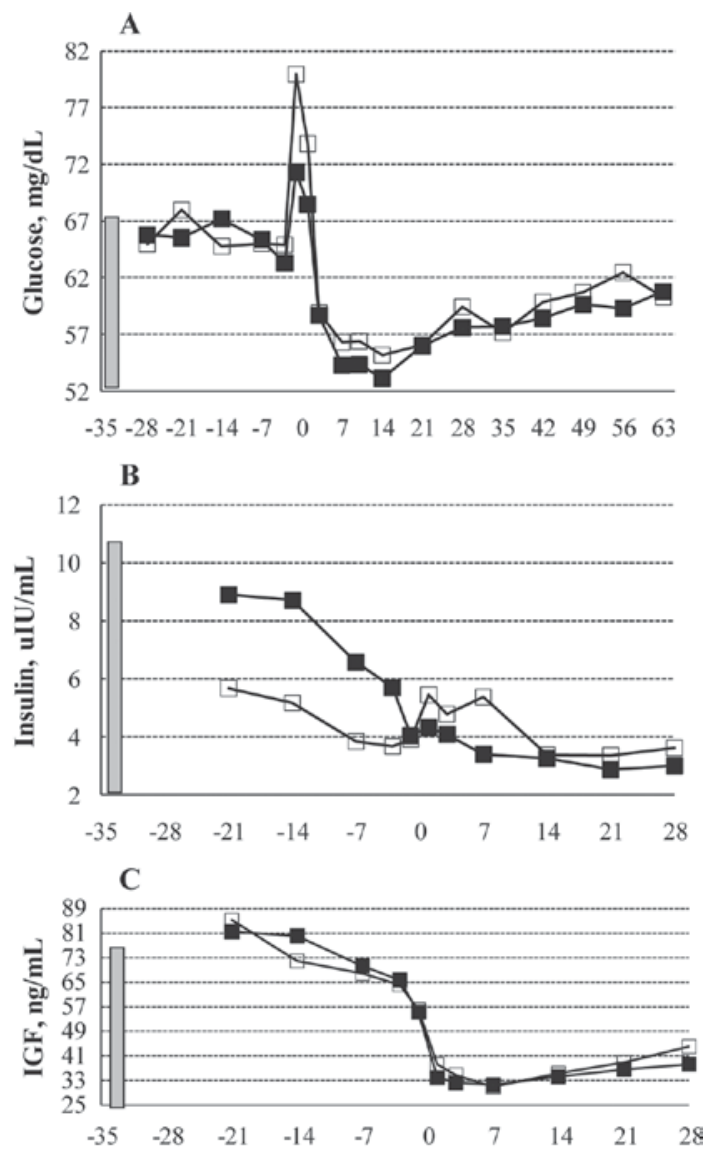

D

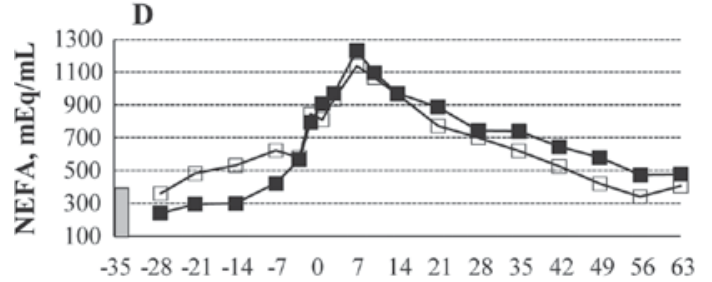

Day Relative to Parturition

Figure 3. Effects of prepartal feeding level $(\mathbf{\square}, \mathrm{AL}=$ ad libitum; $\square, \mathrm{FR}=30 \%$ feed restriction) on (A) plasma glucose, (B) insulin, (C) IGF-1, and (D) NEFA concentrations during the periparturient period. Probabilities of significance for effects of prepartal feeding level, time, and prepartal feeding level by time interaction were $0.18,0.0001$, and 0.02 during the prepartum period $(\mathrm{SEM}=1.67)$ and $0.30,0.0001$, and 0.60 during the postpartum period $(\mathrm{SEM}=1.64)$, respectively (panel A). Probabilities of significance for effects of prepartal feeding level, time, and prepartal feeding level by time interaction were $0.0001,0.0001$, and 0.0003 during the prepartum period $(\mathrm{SEM}=0.50)$ and $0.46,0.04$, and 0.78 during the postpartum period $(\mathrm{SEM}=1.00)$, respectively (panel B). Probabilities of significance for effects of prepartal feeding level, time, and prepartal feeding level by time interaction were $0.65,0.0001$, and 0.09 during the prepartum period (SEM $=$ 3.08 ) and $0.38,0.0005$, and 0.51 during the postpartum period (SEM $=2.93$ ), respectively (panel C). Probabilities of significance for effects of prepartal feeding level, time, and prepartal feeding level by time interaction were $0.0001,0.0001$, and 0.008 during the prepartum period $(\mathrm{SEM}=39)$ and $0.10,0.0001$, and 0.94 during the postpartum period $(\mathrm{SEM}=62)$, respectively (panel D). The mean covariate values $( \pm \mathrm{SE})$ were $66.4 \pm 1.5 \mathrm{mg} / \mathrm{dL}, 11.1 \pm 0.8 \mu \mathrm{UI} / \mathrm{mL}, 75.4 \pm 4.3 \mathrm{ng} /$ $\mathrm{mL}$, and $406 \pm 34 \mathrm{mEq} / \mathrm{mL}$ for plasma glucose, insulin, IGF-1, and NEFA, respectively.
Cows subjected to prepartal FR had greater milk antioxidant capacity $(P<0.0008)$ in the subsequent lactation than those fed AL. The FRAP activity was positively correlated with $\mathrm{C}_{16: 0}(\mathrm{r}=0.27, P<0.002)$, $\mathrm{C}_{18: 0}(\mathrm{r}=0.21, P<0.02)$, and total saturated FA $(\mathrm{r}=0.22, P<0.01)$ proportions, as well as the saturated FA:unsaturated FA ratio $(\mathrm{r}=0.25, P<$ $0.004)$, and negatively correlated with $\mathrm{C}_{18: 1, \mathrm{n}-12}$ ( $\mathrm{r}$ $=-0.25, P<0.04), \mathrm{CLA}_{18: 2, \mathrm{n}-9,12}(\mathrm{r}=-0.21, P<$ $0.02)$, and total unsaturated FA $(\mathrm{r}=-0.22, P<$ $0.01)$ proportions.

\section{Blood Biochemistry}

Plasma glucose concentration remained constant from the initiation of treatment until $3 \mathrm{~d}$ before parturition and then dramatically increased. It sharply declined within 1 wk postpartum and then increased gradually (Figure 3A). The increase in glucose concentration toward calving was greater for FR cows than for AL cows $(\mathrm{FL} \times$ time interaction; $P<0.02)$ but the rate of increase postpartum was similar. Overall, the mean concentrations prepartum and in early lactation did not differ by prepartal FL (Table 5).

Plasma insulin concentration continuously decreased until parturition, with the decline being greater for $\mathrm{AL}$ cows than FR cows $(\mathrm{FL} \times$ time interaction; $P<0.0003$; Figure $3 \mathrm{~B})$. Even though the AL cows had a much more rapid decline, the concentration at calving was similar between the 2 groups because of the much higher concentration of the AL cows at $d-21$. The mean plasma insulin concentration prepartum for cows in the $\mathrm{AL}$ group was 1.5-fold greater than that for cows in the FR group $(P<0.0001 ;$ Table 5$)$. There was no carryover prepartal FL effect on plasma insulin concentration in early lactation.

Prepartum FL did not affect the mean plasma IGF-1 concentrations during the prepartum period (Table 3 ). The IGF-1 concentration of FR cows initially tended to decrease more rapidly than that of AL cows but during the last week of gestation the concentrations declined at the same rate for the 2 groups $(\mathrm{FL} \times$ time interaction; $P<0.09$; Figure 3C). No differences in concentration or the pattern of change between AL and FR cows in early lactation were observed (Table 5, Figure 3C).

Plasma NEFA concentration continuously increased until d 7 postpartum and then decreased until 56 DIM (Figure 3D). Initially, prepartum concentrations were higher for FR than AL but by d -3 they were similar and the rate of increase from that point on until $\mathrm{d} 7$ was the same between the 2 groups (FL $\times$ time interaction; $P<0.008)$. The rate of decline after parturition was similar between the 2 groups. Although cows subjected to FR had a greater mean plasma NEFA concentration 
Table 4. Effects of prepartal feeding level on BW and BCS during the periparturient period

\begin{tabular}{lcccc}
\hline & \multicolumn{2}{c}{ Feeding level $^{2}$} & & \\
\cline { 2 - 3 } Variable $^{1}$ & AL & FR & SEM & $P>F$ \\
\hline BW, kg (covariate, on d -34) & 682 & 682 & 13 & 0.97 \\
Relative changes in BW, \% & & & & \\
From d -34 to d 1 & -2.89 & -6.04 & 0.66 & 0.0007 \\
From d 1 to d 14 & -9.17 & -7.98 & 0.68 & 0.19 \\
From d 1 to d 28 & -13.01 & -10.54 & 0.83 & 0.03 \\
From d 1 to d 56 & -12.40 & -9.72 & 1.02 & 0.05 \\
BCS (covariate, on d -34) & 3.35 & 3.37 & 0.03 & 0.63 \\
Relative changes in BCS, \% & & & & \\
From d -34 to d 1 & 0.67 & -2.30 & 1.08 & 0.05 \\
From d 1 to d 14 & -8.12 & -5.11 & 1.32 & 0.09 \\
From d 1 to d 28 & -13.61 & -10.42 & 1.46 & 0.10 \\
From d 1 to d 56 & -15.31 & -12.90 & 1.57 & 0.26 \\
\hline
\end{tabular}

${ }^{1}$ Relative changes in BW and BCS: from $\mathrm{d}-34$ to $\mathrm{d} 1=[(\mathrm{d} 1-\mathrm{d} 34) \times 100] / \mathrm{d} 34$; from $\mathrm{d} 1$ to $\mathrm{d} 14=[(\mathrm{d} 14-$ $\mathrm{d} 1) \times 100] / \mathrm{d} 1 ;$ from $\mathrm{d} 1$ to $\mathrm{d} 28=[(\mathrm{d} 28-\mathrm{d} 1) \times 100] / \mathrm{d} 1$; from d 1 to d $56=[(\mathrm{d} 56-\mathrm{d} 1) \times 100] / \mathrm{d} 1$.

${ }^{2} \mathrm{AL}=$ ad libitum; $\mathrm{FR}=30 \%$ feed restriction.

prepartum than cows fed AL $(P<0.0001)$, the mean concentration postpartum tended to be less for the former than for the latter $(P<0.10$; Table 5$)$.

Plasma BHBA concentration postpartum was greater than that prepartum, with no main effect of prepartal FL during either period (Figure 4A; Table 5). As parturition approached, the rate of increase in BHBA concentrations was greater for cows in the AL group than cows in the FR group $(P<0.02)$, but the rate of decline was similar as lactation advanced.

Plasma acetate concentration for all cows gradually decreased until parturition and then increased after parturition (Figure 4B). The mean plasma acetate concentration prepartum was greater for AL cows than for FR cows $(P<0.0002$; Table 5$)$, whereas the concentration postpartum was not affected by prepartal FL. No FL $\times$ time effect was observed on plasma acetate concentration during the periparturient period.

Cows in the AL group had a greater mean plasma leptin concentration prepartum than cows in the FR group $(P<0.0001$; Table 5). Although concentrations decreased for both groups as gestation progressed, the decline was more pronounced for AL cows than for FR cows $(P<0.009 ;$ Figure $4 \mathrm{C})$. During the postpartum

Table 5. Effects of prepartal feeding level on peripartum metabolic profile

\begin{tabular}{|c|c|c|c|c|}
\hline \multirow[b]{2}{*}{ Variable $^{1}$} & \multicolumn{2}{|c|}{ Feeding level $^{2}$} & \multirow[b]{2}{*}{ SEM } & \multirow[b]{2}{*}{$P>F$} \\
\hline & $\mathrm{AL}$ & FR & & \\
\hline \multicolumn{5}{|l|}{ Prepartum } \\
\hline Glucose, $\mathrm{mg} / \mathrm{dL}^{\mathrm{a}, \mathrm{b}}$ & 66.4 & 67.9 & 0.79 & 0.18 \\
\hline Insulin, $\mu \mathrm{IU} / \mathrm{mL}^{\mathrm{a}, \mathrm{c}, \mathrm{d}}$ & 6.8 & 4.4 & 0.36 & 0.0001 \\
\hline IGF-1, $\mathrm{ng} / \mathrm{mL}^{\mathrm{a}, \mathrm{e}}$ & 70.6 & 69.1 & 2.29 & 0.65 \\
\hline $\mathrm{NEFA}, \mathrm{mEq} / \mathrm{mL}^{\mathrm{a}, \mathrm{c}, \mathrm{d}}$ & 436 & 570 & 23 & 0.0001 \\
\hline $\mathrm{BHBA}, \mathrm{mg} / \mathrm{dL}^{\mathrm{a}, \mathrm{b}}$ & 6.8 & 6.8 & 0.22 & 0.87 \\
\hline Acetate, $\mathrm{mmol} / \mathrm{L}^{\mathrm{a}}$ & 0.55 & 0.43 & 0.02 & 0.0002 \\
\hline Leptin, $\mathrm{ng} / \mathrm{mL}^{\mathrm{a}, \mathrm{c}}$ & 14.2 & 10.8 & 0.52 & 0.0001 \\
\hline Cholecystokinin, pmol/L & 1.32 & 1.16 & 0.16 & 0.51 \\
\hline \multicolumn{5}{|l|}{ Postpartum } \\
\hline Glucose, $\mathrm{mg} / \mathrm{dL}^{\mathrm{a}}$ & 58.2 & 59.7 & 1.06 & 0.30 \\
\hline Insulin, $\mu \mathrm{IU} / \mathrm{mL}^{\mathrm{a}}$ & 3.5 & 4.3 & 0.80 & 0.46 \\
\hline IGF-1, ng/mL ${ }^{\mathrm{a}}$ & 34.5 & 37.0 & 2.13 & 0.38 \\
\hline $\mathrm{NEFA}, \mathrm{mEq} / \mathrm{mL}^{\mathrm{a}}$ & 810 & 725 & 38 & 0.10 \\
\hline $\mathrm{BHBA}, \mathrm{mg} / \mathrm{dL}^{\mathrm{a}}$ & 11.4 & 11.6 & 0.96 & 0.88 \\
\hline Acetate, $\mathrm{mmol} / \mathrm{L}^{\mathrm{a}}$ & 0.69 & 0.70 & 0.02 & 0.80 \\
\hline Leptin, $\mathrm{ng} / \mathrm{mL}^{\mathrm{a}}$ & 8.6 & 8.9 & 0.40 & 0.59 \\
\hline Cholecystokinin, $\mathrm{pmol} / \mathrm{L}^{\mathrm{a}}$ & 1.62 & 1.88 & 0.20 & 0.36 \\
\hline
\end{tabular}

${ }^{\mathrm{a}}$ Time effect, $0.0001<P \leq 0.05 ;{ }^{\mathrm{b}}$ prepartal feeding level by time interaction effect, $0.01<P \leq 0.05$; ${ }^{\mathrm{c}}$ prepartal feeding level by time interaction effect, $0.0001<P \leq 0.01$; ${ }^{\mathrm{d}}$ prepartal fatty acid source by time interaction effect, $0.01<P \leq 0.05$; ${ }^{\mathrm{e}}$ prepartal feeding level by time interaction effect, $0.05<P \leq 0.10$.

${ }^{1} \mathrm{AL}=$ ad libitum; $\mathrm{FR}=30 \%$ feed restriction.

${ }^{2}$ Prepartum data cover the last $27 \mathrm{~d}$ of gestation, and postpartum data cover the first $63 \mathrm{~d}$ of lactation. 

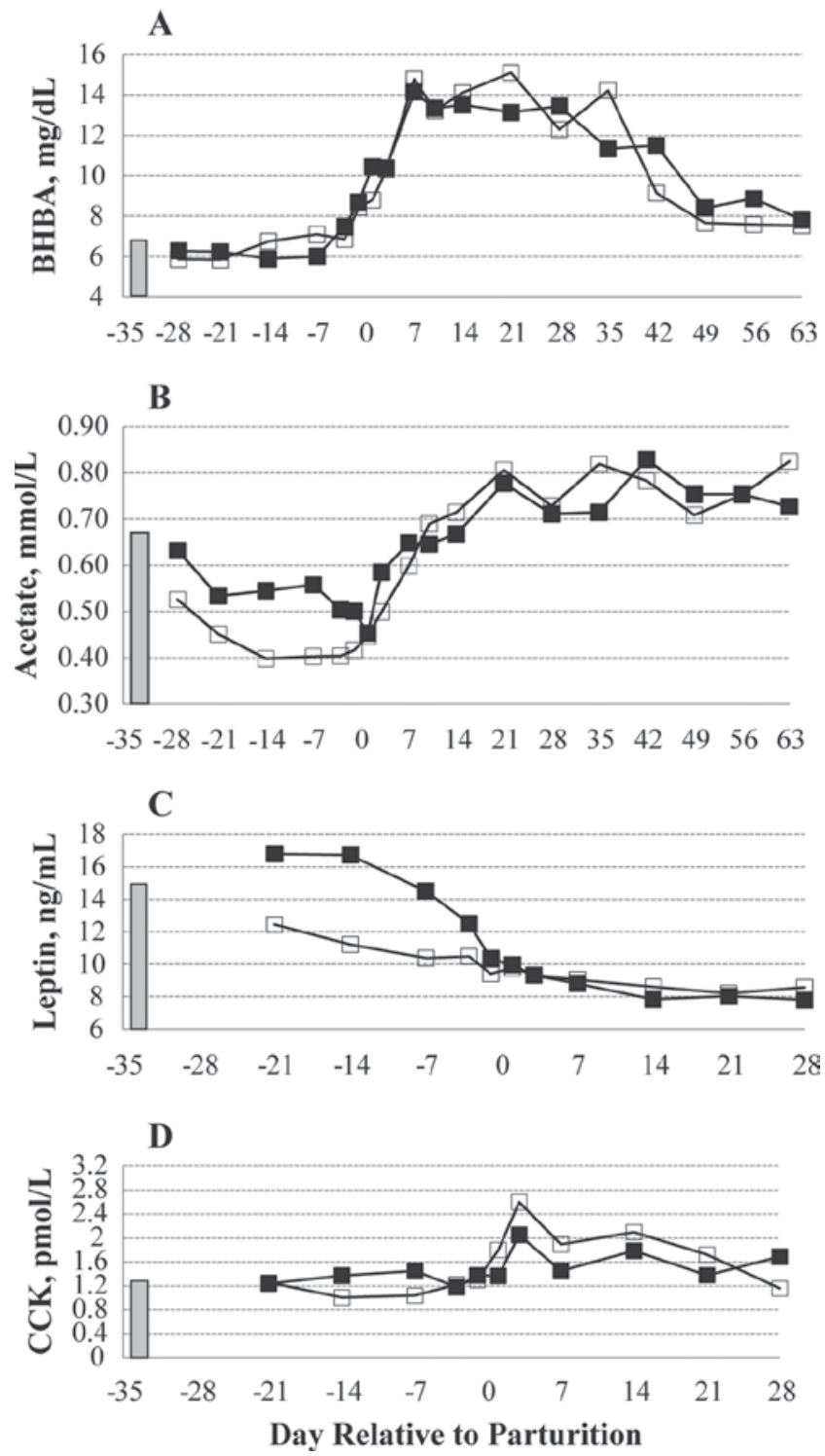

Figure 4. Effects of prepartal feeding level (ם, AL = ad libitum; $\square, \mathrm{FR}=30 \%$ feed restriction) on plasma (A) BHBA, (B) acetate, (C) leptin, and (D) cholecystokinin (CCK) concentrations during the periparturient period. Probabilities of significance for effects of prepartal feeding level, time, and prepartal feeding level by time interaction were $0.87,0.0001$, and 0.02 during the prepartum period $(\mathrm{SEM}=$ 0.36 ) and $0.88,0.0001$, and 0.11 during the postpartum period (SEM $=1.61$ ), respectively (panel A). Probabilities of significance for effects of prepartal feeding level, time, and prepartal feeding level by time interaction were $0.0002,0.0002$, and 0.68 during the prepartum period $(\mathrm{SEM}=0.03)$ and $0.80,0.0001$, and 0.39 during the postpartum period $(\mathrm{SEM}=0.05)$, respectively (panel B). Probabilities of significance for effects of prepartal feeding level, time, and prepartal feeding level by time interaction were $0.0001,0.0001$, and 0.009 during the prepartum period $(\mathrm{SEM}=0.68)$ and $0.59,0.0001$, and 0.48 during the postpartum period $(\mathrm{SEM}=0.48)$, respectively (panel $\mathrm{C})$. Probabilities of significance for effects of prepartal feeding level, time, and prepartal feeding level by time interaction were $0.51,0.98$, and 0.78 during the prepartum period $(\mathrm{SEM}=0.22)$ and $0.36,0.009$, and 0.62 during the postpartum period $(\mathrm{SEM}=0.34)$, respectively (panel $\mathrm{D})$. The mean covariate values $( \pm \mathrm{SE})$ were $6.9 \pm 0.3 \mathrm{mg} / \mathrm{dL}, 0.60 \pm 0.04 \mathrm{mmol} / \mathrm{L}$, $15.0 \pm 1.1 \mathrm{ng} / \mathrm{mL}$, and $1.10 \pm 0.23 \mathrm{pmol} / \mathrm{L}$ for plasma BHBA, acetate, leptin, and CCK, respectively.
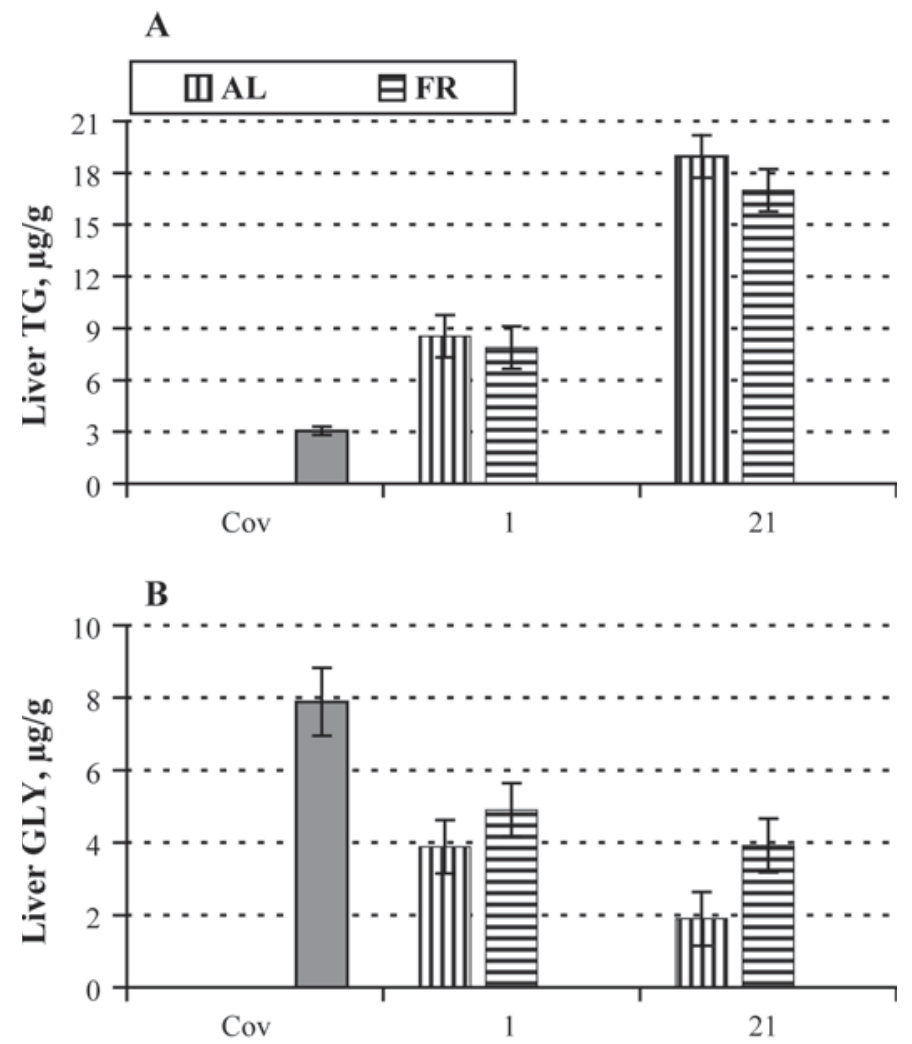

Day Relative to Parturition

Figure 5. Effects of prepartal feeding level $(\mathrm{AL}=$ ad libitum; FR $=30 \%$ feed restriction) on liver (A) triglyceride (TG) and (B) glycogen (GLY) concentrations during the periparturient period. Probabilities of significance were $0.37,0.0001$, and 0.58 for effects of prepartal feeding level, time, and prepartal feeding level by time interaction, respectively $(\mathrm{SEM}=1.53$; panel A). Probabilities of significance were 0.08 , 0.004 , and 0.32 for effects of prepartal feeding level, time, and prepartal feeding level by time interaction $(\mathrm{SEM}=0.84$; panel $\mathrm{B})$.

period, plasma leptin concentration continued to decrease but at a similar rate between AL and FR cows.

Prepartal FL affected neither the mean plasma CCK concentration (Table 5) nor its pattern (Figure 4D) during the periparturient period. The mean plasma CCK concentration during the prepartum period was lower than that during early lactation.

In general, no main effect of prepartal FAS on plasma metabolites was observed during the periparturient period, but there was a significant prepartal FAS by time interaction effect on plasma insulin $(P<0.02)$ and NEFA $(P<0.07)$ concentrations. The rate of decrease in plasma insulin concentration and the rate of increase in plasma NEFA concentration toward parturition were greater for cows fed $\mathrm{C}$ than for those fed $\mathrm{L}$ and $\mathrm{F}$.

\section{Liver Parameters}

Hepatic TG content doubled at parturition relative to the preexperimental concentration and approxi- 
mately doubled again on d 21 postpartum (Figure 5A). Prepartal FL did not affect hepatic TG content postpartum $(P<0.37)$. Changes in hepatic GLY content were opposite of those in hepatic TG content; GLY decreased by approximately $50 \%$ at parturition and continued to decrease by $75 \%$ on $d 21$ postpartum compared with that measured at the beginning of the experiment (Figure 5B). Cows in the FR group tended to have greater hepatic GLY content postpartum than cows in the AL group $(P<0.08$; Figure 5B). Prepartal FAS did not affect hepatic TG $(13.11 \pm 1.47 \mu \mathrm{g} / \mathrm{g}$ of $\mathrm{DM})$ or GLY $(3.60 \pm 0.88 \mu \mathrm{g} / \mathrm{g}$ of $\mathrm{DM})$ contents postpartum.

\section{DISCUSSION}

\section{Feeding Level}

Intake and Productivity. Because of the feed restriction that was imposed during the close-up dry period, FR cows did not experience the decrease in intake that was evident with the AL cows (Figure 1A). In addition, their postpartum DMI as a percentage of BW was higher because they lost less BW than AL cows (Tables 3 and 4). This is in agreement with the study of Agenäs et al. (2003), which reported that cows with restricted energy intakes during the dry period had increased postpartum feed intake 2 wk after calving and lower loss of BW compared with cows with high energy intakes prepartum.

Minimal carryover effects of prepartal FR on productivity after parturition were observed. Milk yield was not affected by prepartal FL (Table 3; Figure 2A). This is consistent with the results of Holcomb et al. (2001) that showed no difference in postpartum DMI and milk production in cows consuming $8 \mathrm{~kg}$ of $\mathrm{DM} / \mathrm{d}$ compared with cows consuming $12.4 \mathrm{~kg}$ of DM/d during the closeup period. With the exception of milk fat content, milk composition was unaffected by prepartal FL (Table 3). Milk fat percentage was higher with AL than with FR, a finding that is difficult to explain and is in contrast to that of Agenäs et al. (2003) and Dewhurst et al. (2002), who reported no effect of prepartal FR on milk fat content. However, it is in agreement with Holcomb et al. (2001), who reported a decreased milk fat percentage in cows that were feed-restricted in the close-up dry period. The lack of a milk protein or lactose response to prepartal FL is consistent with Nielsen et al. (2003), who reported no differences in milk protein and lactose concentrations between cows fed AL and those subjected to $35 \%$ FR during the close-up period. Milk fat composition in general was also unaffected by prepartal FL, which is consistent with the fact that the cows were fed a common diet postpartum. However, the increase in FRAP in FR cows (Table 3) could be explained by a slight increase in proportions of saturated FA, which indicates body fat mobilization (Grummer, 1991). Indeed, milk FRAP was positively correlated with saturated FA content $(\mathrm{r}=0.22, P<0.01)$.

Metabolic Profile and Hepatic Lipidosis. In general, negative EB during the transition period is coupled with reduced plasma glucose, insulin, leptin, and IGF-1 concentrations with concomitant increases in plasma BHBA and NEFA concentrations (Markiewicz et al., 2004). This pattern of reduced glucose (Figure $3 \mathrm{~A}$ ), insulin (Figure 3B), leptin (Figure 4C), and IGF-1 (Figure $3 \mathrm{C}$ ) concentrations in the postpartum period relative to prepartum was observed in the current study and is related to the deficiency of glucogenic precursor intake relative to that needed for milk synthesis. In agreement with current data (Table 5; Figures 1, 3, and 5), the decrease in DMI toward parturition was accompanied by elevated plasma NEFA and hepatic TG concentrations and decreased plasma insulin and hepatic GLY concentrations during early lactation in dry cows that were fed AL $(21 \mathrm{~kg} / \mathrm{d})$ compared with FR (7 kg/d; Van Den Top et al., 1996). A similar result was observed in cows that were fed unrestricted energy intake $(164 \mathrm{MJ} / \mathrm{d})$ compared with those on restricted energy intake (94 MJ/d; Rukkwamsuk et al., 2000) and in those fed $150 \%$ of $\mathrm{NE}_{\mathrm{L}}$ requirement compared with $80 \%$ of $\mathrm{NE}_{\mathrm{L}}$ requirement (Dann et al., 2006).

Glucose concentration peaked at calving and was lower postpartum than prepartum (Figure 3A; Table 5) as reported by others (Vazquez-Añón et al., 1994; Dann et al., 1999). The peak at calving may be related to the release of glucocorticoids immediately before calving that stimulate glycogenolysis and gluconeogenesis, whereas low glucose concentration postpartum is probably related to DMI that is insufficient to meet the glucose requirements for milk synthesis (Leury et al., 2003). Although prepartum plasma glucose was unaffected by FR, prepartum insulin was higher in AL cows than FR cows (Table 5). This probably is a result of the higher DMI of AL cows (Table 3) and subsequently a greater availability of glucogenic precursors (Roche, 2007). Grum et al. (1996) and Holtenius et al. (2003) also reported low insulin concentrations with restricted feeding prepartum.

Serum IGF-I concentration is highest during the dry period and then its synthesis is depressed during early lactation when cows are in negative EB (Sharma et al., 1994). In the present study, IGF concentration demonstrated this pattern (Figure $3 \mathrm{C}$ ) and did not respond to differences in prepartum DMI (Table 3; Figure 1); in agreement with Doepel et al. (2002), in which IGF1 concentrations were unaffected by increased protein and energy intake prepartum. 
Elevated NEFA concentrations prepartum in FR cows versus AL cows (Table 5; Figure 3D) reflected the negative EB of the FR cows (Table 3; Figure 1B) and subsequent mobilization of body fat reserves (Grummer, 1993). Plasma NEFA also tended to be lower postpartum in FR cows compared with AL cows (Figure 3D, Table 5). Holcomb et al. (2001) and Nielsen et al. (2003) reported that cows subjected to prepartal FR had lower plasma NEFA and BHBA concentrations in early lactation than did cows fed AL. Similarly, cows with restricted energy intakes during the dry period had lower NEFA concentrations during the first weeks postpartum compared with cows with high energy intakes prepartum (Holtenius et al., 2003). Postpartum plasma NEFA and liver TG concentrations have been shown to be more correlated with changes in DM (Holtenius et al., 2003; Drackley et al., 2005) and energy (Rabelo et al., 2005) intakes during the close-up period rather than with mean DM and energy intakes (Mashek and Grummer, 2003b).

Normally, the majority of plasma acetate originates from the rumen but in the case of negative EB the liver contributes as well (Herdt, 1988). A higher plasma acetate concentration during the prepartum period in $\mathrm{AL}$ cows than FR cows (Figure 4B) could be related to an increased ruminal acetate pool due to the higher DMI (Table 3). Moreover, increased plasma acetate during early lactation in both groups could be related to the negative $\mathrm{EB}$, and the lack of difference between $\mathrm{AL}$ and FR cows could be attributed to the absence of carryover effects on intake level during the early postpartum period (Table 3).

Similar to the prepartum leptin response in the present study (Table 5; Figure 4C), undernourished dry cows (by 40\%) had lower plasma leptin concentration than those fed 30\% excess (Delavaud et al., 1999). Similar to the findings in humans (Boden et al., 1997), in cows (Leury et al., 2003) it was indicated that insulin has a stimulating effect on leptin secretion; therefore, it is possible that the high insulin concentration of $\mathrm{AL}$ cows contributed to their high leptin concentration prepartum (Figures 3B and 4C). Postpartum, no difference was observed in leptin levels between AL and FR cows, which would corroborate with the similarities in insulin concentration, BCS, and degree of negative EB between the 2 groups (Leury et al., 2003). Leptin (Figure 4C) and CCK (Figure 4D) concentrations were lower postpartum than prepartum; this may also be related to EB (Block et al., 2001) or may be a direct effect of lactation itself (Holtenius et al., 2003).

Hepatic TG content was higher postpartum than prepartum, coinciding with the increased concentration of NEFA in the postpartum period. This indicates that lipolysis and the release of NEFA were ongoing throughout early lactation. Lipolytic rates reported by McNamara and Hillers (1986) substantiate this finding. Prepartum FL had no effect on postpartum liver TG concentration (Figure 5) in spite of FR cows mobilizing more body tissue precalving than $\mathrm{AL}$ cows (BW loss of 41 vs. $20 \mathrm{~kg}$ ). However, the lack of a TG response is in agreement with the lack of a postpartum NEFA and peripartum IGF-1 response to FL (Table 5; Figures $3 \mathrm{C}$ and $3 \mathrm{D}$ ) because these 2 variables are the most closely related to fat mobilization (Hachenberg et al., 2007). Additionally, the postpartum loss of BW for FR cows was numerically less than that of AR cows, which indicates that the FR cows may have been mobilizing less fat than the AR cows, which may have contributed to the similarity in liver TG between the 2 treatments. The hepatic TG levels in the present study are similar to that reported by Doepel et al. (2002).

In contrast to the results for liver TG, FR cows tended to have a higher concentration of liver GLY in the postpartum period than AL cows (Figure 5B). This may be related to the numerically higher DMI and subsequently starch intake of these cows without a corresponding increase in milk yield (Table 3; Figure $2 \mathrm{~A}$ ). This would suggest a channeling of nutrients to body stores as opposed to milk synthesis. In general, FR reduces de novo FA synthesis and FA oxidation and increases glucose production via decreasing activities of hepatic lipogenic enzymes (Murondoti et al., 2004b) and increasing activities of hepatic gluconeogenic enzymes (Murondoti et al., 2004a), respectively.

\section{Dietary Fatty Acid Source}

Performance and Lactation. Oilseeds and their oils have been extensively used in feeding lactating cows to enrich milk with n-3 FA and CLA. However, in vivo studies examining the role of PUFA in modulating hepatic lipid metabolism in dairy cows, particularly transition dairy cows, are limited. Canola (Brassica napus L., Brassiceae), linola, and flax (Linum usitatissimum, Linaceae) are rich in oleic, linoleic, and linolenic acids, respectively (Siemens and Daun, 2005). Linola is genetically modified flax in which the concentration of linolenic acid is decreased and that of linoleic acid is increased (Ward et al., 2002). To test the effect of PUFA on response variables, $\mathrm{C}$ was used as a control instead of a fat source rich in saturated FA so that confounding effects of fat form could be avoided.

Except for milk yield (Figure 2C), prepartal FAS had negligible effect on performance and lactation variables. This may be explained by the provision of prepartum isocaloric and isonitrogenous diets, discontinuation of the oilseed supplementation after parturition, and the ruminal biohydrogenation process. Moreover, these oil- 
seeds are rich in amino acids, which could compensate for suppressed microbial protein synthesis due to the adverse effect of high fat on fiber degradation, and contribute to milk protein concentration (Cant et al., 1993). In general, feeding $\mathrm{F}$ has no detrimental effects on performance and lactation, but is associated with decreased proportion of palmitic and stearic acids in milk, which may be indicators of decreased FA supply to the liver (Grummer, 1991). Petit and Benchaar (2007) tested the effect of prepartal provision of whole $\mathrm{F}$ for the last $6 \mathrm{wk}$ of gestation only and reported no differences in DMI and milk production and milk FA profile compared with prepartal provision of Megalac. However, Petit et al. (2007) reported that cows fed whole F consumed more DM and lost less BW prepartum and consumed more DM postpartum and produced more milk with a lower fat content than cows fed a fat source rich in saturated FA, at feeding rates of 3.3 and $11.0 \%$ on DM basis, during the prepartum and postpartum periods, respectively. In the current experiment, prepartal FAS had no effect on mean DMI during the periparturient period, but cows fed $\mathrm{F}$ had less DMI depression toward calving and a greater rate of DMI increase after calving than cows fed $\mathrm{C}$ and $\mathrm{L}$ (Figure 2B). In a study conducted by Givens et al. (2003), whole rapeseed $(2 \mathrm{~kg} / \mathrm{d})$ fed to transition cows depressed DMI, milk production, and milk fat concentration, accompanied by increased cis-oleic acid proportion and decreased short-chain and medium-chain FA proportions.

The FRAP is a reliable and valid measurement of total antioxidant capacity of milk based on the reduction of ferric iron to its ferrous form and reflects sensitivity to oxidation when the shelf-life of dairy products is evaluated (Smet et al., 2008). In humans, it was shown that total antioxidant capacity as measured by FRAP and free radical scavenging activity were highly correlated and that FRAP level decreased during the course of lactation, being 590, 454, and $168 \mathrm{pmol} / \mathrm{L}$ in colostrum, transition milk, and milk, respectively (Zarban et al., 2009). In cows, it was also demonstrated that plasma FRAP decreases over lactation, which was lower for cows fed a high-energy diet than for cows fed a low-energy diet (Wullepit et al., 2009). Prepartal FAS did not affect FRAP activity, which could be related to the similarity in milk FA profile among the treatments that resulted from ruminal biohydrogenation of dietary FA (Jenkins, 1993) as well as discontinuation of the oil seeds at calving and feeding all cows the same isocaloric diet during early lactation. Milk unsaturated FA concentration was negatively correlated with the FRAP activity $(\mathrm{r}=-0.22, P<0.01)$. The lack of response of FRAP to FAS could also be related to the lack of a FAS effect on the milk fat unsaturated FA:saturated FA ratio.
Metabolic Profile and Hepatic Lipidosis. In this experiment, none of the plasma metabolite concentrations were affected by prepartal FAS. This is probably a result of the oilseeds being included in the diets at equal amount in their unprotected form during the close-up period only. The degree of unsaturation affects insulin, IGF-1, leptin, and CCK secretions (Choi and Palmquist, 1996; Stein et al., 1997). Because these were unaffected by FAS in the current study it suggests that the amount and chain length of FA reaching the duodenum was likely similar and their saturation completed before reaching the splanchnic tissues (Jenkins, 1993). Contrary to our results, it was shown that when whole $\mathrm{F}$ was fed both prepartum (3.3\%) and postpartum (11.0\%), plasma NEFA and BHBA concentrations and liver TG content were reduced, and plasma glucose concentration and liver GLY content were increased (Petit et al., 2007).

Recent studies have investigated if PUFA can alter hepatic lipid metabolism in dairy cattle. Contrary to our hypothesis, which stated that the provision of PUFA source would alter hepatic lipid metabolism and consequently reduce hepatic steatosis and improve glucogenic capacity, prepartal FAS had no effect on liver TG content. Our hypothesis was based on data reported by Mashek et al. (2002) and Mashek and Grummer (2003a). Those authors reported that liver slices incubated in media supplemented with linoleic and linolenic acids have a reduced capacity for esterification and cellular TG. If the same situation occurred in vivo, then cows receiving $\mathrm{L}$ and $\mathrm{F}$ would have lower hepatic TG concentrations than cows fed C. This was not the case and a few possible reasons for a lack of response can be proposed. First, the effect in vitro might have occurred as a result of the FA having a direct effect on the liver tissue; in vivo, this may not have occurred due to FA transformations in the rumen as well as to the concentrations of FA in direct contact with the liver being much lower than in vitro. Second, a hepatic response to PUFA may only occur in the continuous presence of the fatty acids; in the present study, the FA were only supplied for 3 wk prepartum whereas the liver measurements were made in the postpartum period. Moreover, in vivo studies dealing with abomasal and dietary delivery of fat sources rich in PUFA with respect to hepatic lipid metabolism and metabolic responses in ruminants, especially during the periparturient period, are ambiguous (Grummer, 2008; Pires and Grummer, 2008).

\section{CONCLUSIONS}

In conclusion, restricting DMI before parturition while still meeting nutrient requirements improved ana- 
bolic status during early lactation, as reflected by lower BW loss and less severe negative EB. Lack of prepartal FAS effects on milk composition and metabolic profile may be attributed to the FA becoming saturated in the rumen and also to discontinuation of feeding FA after parturition. Neither prepartal FL nor FAS altered hepatic TG content. Further studies should consider provision of ruminally protected PUFA during the entire periparturient period.

\section{ACKNOWLEDGMENTS}

The authors thank Marcos Colazo, Erica Holm, Laura-Anne Kutryk, and Tammy Whyte (University of Alberta, Edmonton, AB, Canada) for their help with conducting the study, and the staff at the University of Alberta Dairy Research and Technology Centre for the care of the experimental animals. We also thank Jocelyn Montgomery and Luis Valencia (University of Alberta, Edmonton, AB, Canada) for the laboratory analysis of the experimental samples. We also extend our thanks to Agricore United Ltd. (Saskatoon, SK, Canada) for graciously donating the linola seed. Finally, we acknowledge the Alberta Livestock Industry Development Fund and Alberta Milk for their financial support of this project.

\section{REFERENCES}

Agenäs, S., E. Burstedt, and K. Holtenius. 2003. Effects of feeding intensity during the dry period. 1. Feed intake, body weight, and milk production. J. Dairy Sci. 86:870-882.

AOAC. 1990. Official Methods of Analysis. Vol. I. 15th ed. Association of Official Analytical Chemist, Arlington, VA.

Bell, J. A., J. M. Griinari, and J. J. Kennelly. 2006. Effect of safflower oil, flaxseed oil, monensin, and vitamin $\mathrm{E}$ on concentration of conjugated linoleic acid in bovine milk fat. J. Dairy Sci. 89:733-748.

Benzie, I. F. F., and J. J. Strain. 1999. Ferric reducing/antioxidant power assay: Direct measure of total antioxidant activity of biological fluids and modified version for simultaneous measurement of total antioxidant power and ascorbic acid concentration. Pages 15-27 in Methods in Enzymology. Vol. 299. L. Packer, ed. Academic Press, Orlando, FL.

Block, S. S., W. R. Butler, R. A. Ehrhardt, A. W. Bell, M. E. Van Amburgh, and Y. R. Boisclair. 2001. Decreased concentration of plasma leptin in periparturient dairy cows is caused by negative energy balance. J. Endocrinol. 171:339-348.

Boden, G., X. Chen, J. W. Kolaczynski, and M. Polansky. 1997. Effects of prolonged hyperinsulinemia on serum leptin in normal human subjects. J. Clin. Invest. 100:1107-1113.

Bradford, B. J., K. J. Harvatine, and M. S. Allen. 2008. Dietary unsaturated fatty acids increase plasma glucagon-like peptide- 1 and cholecystokinin and may decrease premeal ghrelin in lactating dairy cows. J. Dairy Sci. 91:1443-1450.

Cant, J. P., J. DePeters, and R. L. Baldwin. 1993. Mammary amino acid utilization in dairy cows fed fat and its relationship to milk protein depression. J. Dairy Sci. 76:762-774.

CCAC. 1993. Guide to the Care and Use of Experimental Animals. Canadian Council on Animal Care. Vol. 1. 2nd ed. Bradda Printing Services Inc., Ottawa, ON, Canada.

Choi, B. R., and D. L. Palmquist. 1996. High fat diets increase plasma cholecystokinin and pancreatic polypeptide, and decrease plasma insulin and feed intake in lactating cows. J. Nutr. 126:29132919.

Coppock, C. E., C. H. Noller, S. A. Wolfe, C. J. Callahan, and J. S. Baker. 1972. Effect of forage-concentrate ratio in complete feeds fed ad libitum on feed intake prepartum and the occurrence of abomasal displacement in dairy cows. J. Dairy Sci. 55:783-789.

Dann, H. M., N. B. Litherland, J. P. Underwood, M. Bionaz, A. D'Angelo, J. W. McFadden, and J. K. Drackley. 2006. Diets during far-off and close-up dry periods affect periparturient metabolism and lactation in multiparous cows. J. Dairy Sci. 89:3563-3577.

Dann, H. M., G. A. Varga, and D. E. Putnam. 1999. Improving energy supply to late gestation and early postpartum dairy cows. J. Dairy Sci. 82:1765-1778.

Delavaud, C., Y. Faulconnier, F. Bocquier, and Y. Chilliard. 1999. Pre- and postprandial changes in plasma leptin and insulin concentrations during underfeeding and refeeding in dry cows. Proc. Nutr. Soc. 59:108A.

Delavaud, C., A. Ferlay, Y. Faulconnier, F. Bocquier, G. Kann, and Y. Chilliard. 2002. Plasma leptin concentration in adult cattle: Effects of breed, adiposity, feeding level, and meal intake. J. Anim. Sci. 80:1317-1328.

Dewhurst, R. J., J. M. Moorby, M. S. Dhanoa, and W. J. Fishert. 2002. Effects of level of concentrate feeding during the second gestation of Holstein-Friesian dairy cows. 1. Feed intake and milk production. J. Dairy Sci. 85:169-177.

Doepel, L., and H. Lapierre. 2010. Changes in production and mammary metabolism of dairy cows in response to essential and nonessential amino acid infusions. J. Dairy Sci. 93:3264-3274.

Doepel, L., H. Lapierre, and J. J. Kennelly. 2002. Peripartum performance and metabolism of dairy cows in response to prepartum energy and protein intake. J. Dairy Sci. 85:2315-2334.

Drackley, J. K. 1999. Biology of dairy cows during the transition period: The final frontier? J. Dairy Sci. 82:2259-2273.

Drackley, J. K., H. M. Dann, G. N. Douglas, N. A. J. Guretzky, N. B. Litherland, J. P. Underwood, and J. J. Loor. 2005. Physiological and pathological adaptations in dairy cows that may increase susceptibility to periparturient diseases and disorders. Ital. J. Anim. Sci. 4:323-344.

Edmonson, A. J., I. J. Lean, L. D. Weaver, T. Farver, and G. Webster. 1989. A body condition scoring chart of Holstein dairy cows. J. Dairy Sci. 72:68-78.

Folch, J., M. Lees, and G. H. S. Stanley. 1957. A simple method for the isolation and purification of total lipids from animal tissues. J. Biol. Chem. 226:497-509.

Foster, L. B., and R. T. Dunn. 1973. Stable reagents for determination of serum triglycerides by a colorimetric Hantzsch condensation method. Clin. Chem. 19:338-340.

Givens, D. I., R. Allison, and J. S. Blake. 2003. Enhancement of oleic acid and vitamin $\mathrm{E}$ concentrations of bovine milk using dietary supplements of whole rapeseed and vitamin E. Anim. Res. $52: 531-542$.

Grum, D. E., J. K. Drackley, R. S. Younker, D. W. LaCount, and J. J. Veenhuizen. 1996. Nutrition during the dry period and hepatic lipid metabolism of periparturient dairy cows. J. Dairy Sci. 79:1850-1864.

Grummer, R. R. 1991. Effect of feed on the composition of milk fat. J. Dairy Sci. 74:3244-3257.

Grummer, R. R. 1993. Etiology of lipid-related metabolic disorders in periparturient dairy cows. J. Dairy Sci. 76:3882-3896.

Grummer, R. R. 1995. Impact of changes in organic nutrient metabolism on feeding the transition dairy cow. J. Anim. Sci. 73:28202833.

Grummer, R. R. 2008. Nutritional and management strategies for the prevention of fatty liver in dairy cattle. Vet. J. 176:10-20.

Grummer, R. R., D. G. Mashek, and A. Hayirli. 2004. Dry matter intake and energy balance in the transition period. Vet. Clin. North Am. Food Anim. Pract. 20:447-470.

Hachenberg, S., C. Weinkauf, S. Hiss, and H. Sauerwein. 2007. Evaluation of classification modes potentially suitable to identify metabolic stress in healthy dairy cows during the peripartal period. J. Anim. Sci. 85:1923-1932. 
Hayirli, A., R. R. Grummer, E. V. Nordheim, and P. M. Crump. 2003. Models for predicting dry matter intake of Holsteins during the prefresh transition period. J. Dairy Sci. 86:1771-1779.

Herdt, T. H. 1988. Fuel homeostasis in the ruminant. Vet. Clin. North Am. Food Anim. Pract. 4:213-231.

Holcomb, C. S., H. H. Van Horn, H. H. Head, M. B. Hall, and C. J. Wilcox. 2001. Effects of prepartum dry matter intake and forage percentage on postpartum performance of lactating dairy cows. J. Dairy Sci. 84:2051-2058.

Holtenius, K., S. Agenäs, C. Delavaud, and Y. Chilliard. 2003. Effects of feeding intensity during the dry period. 2. metabolic and hormonal responses. J. Dairy Sci. 86:883-891.

Jenkins, T. C. 1993. Lipid metabolism in the rumen. J. Dairy Sci. 76:3851-3863.

Johnson, M. M., and J. Peters. 1993. An improved method to quantify nonesterified fatty acids in bovine plasma. J. Anim. Sci. 71:753756 .

Leury, B. J., L. H. Baumgard, S. S. Block, N. Segoale, R. A. Ehrhardt, R. P. Rhoads, D. E. Bauman, A. W. Bell, and Y. R. Boisclair. 2003. Effect of insulin and growth hormone on plasma leptin in periparturient dairy cows. Am. J. Physiol. Regul. Integr. Comp. Physiol. 285:R1107-R1115.

Littell, C. R., G. A. Milliken, W. W. Stroup, and F. D. Wolfinger. 1996. SAS ${ }^{\circledR}$ System for Mixed Models. SAS Inst., Inc., Cary, NC.

Lo, S., J. C. Russell, and A. W. Taylor. 1970. Determination of glycogen in small tissue samples. J. Appl. Physiol. 28:234-236.

Markiewicz, H., K. Kuzma, and E. Malinowski. 2004. Relation between particular hormones, cytokines and metabolites during the periparturient period in cows. Med. Weter. 60:356-359.

Mashek, D. G., S. J. Bertics, and R. R. Grummer. 2002. Metabolic fate of long-chain unsaturated fatty acids and their effects on palmitic acid metabolism and gluconeogenesis in bovine hepatocytes. J. Dairy Sci. 85:2283-2289.

Mashek, D. G., and R. R. Grummer. 2003a. Effects of long chain fatty acids on lipid and glucose metabolism in monolayer cultures of bovine hepatocytes. J. Dairy Sci. 86:2390-2396.

Mashek, D. G., and R. R. Grummer. 2003b. Feeding pre-fresh transition cows: Should we maximize feed intake or minimize feed intake depression? J. Dairy Sci. 86(Suppl. 1):11. (Abstr.)

McNamara, J. P., and J. K. Hillers. 1986. Regulation of bovine adipose-tissue metabolism during lactation. 2. Lipolysis response to milk-production and energy-intake. J. Dairy Sci. 69:3042-3050.

Murondoti, A., R. Jorritsma, A. C. Beynen, T. Wensing, and M. J H. Geelen. 2004a. Unrestricted feed intake during the dry period impairs the postpartum oxidation and synthesis of fatty acids in the liver of dairy cows. J. Dairy Sci. 87:672-679.

Murondoti, A., R. Jorritsma, A. C. Beynen, T. Wensing, and M. J. H. Geelen. 2004b. Activities of the enzymes of hepatic gluconeogenesis in periparturient dairy cows with induced fatty liver. J. Dairy Res. 71:129-134.

Nielsen, N. I., K. L. Ingvartsen, and T. Larsen. 2003. Diurnal variation and the effect of feed restriction on plasma and milk metabolites in TMR-fed dairy cows. J. Vet. Med. A Physiol. Pathol. Clin. Med. 50:88-97.

Novak, S., B. K. Treacy, F. R. C. L. Almeida, J. Mao, W. C. Buhi, W. T. Dixon, and G. R. Foxcroft. 2002. Regulation of IGF-1 and porcine oviductal secretory protein (pOSP) secretion into the pig oviduct in the pre-ovulatory period, and effects of previous nutrition. Reprod. Nutr. Dev. 42:355-372.

NRC. 2001. Nutritional Requirements of Dairy Cattle. National Research Council. 7th rev. ed. Natl. Acad. Sci., Washington, DC.

Petit, H. V., and C. Benchaar. 2007. Milk production, milk composition, blood composition, and conception rate of transition dairy cows fed different profiles of fatty acids. Can. J. Anim. Sci. $87: 591-600$.
Petit, H. V., M. F. Palin, and L. Doepel. 2007. Hepatic lipid metabolism in transition dairy cows fed flaxseed. J. Dairy Sci. 90:47804792

Pires, J. A. A., and R. R. Grummer. 2008. Specific fatty acids as metabolic modulators in the dairy cow. R. Bras. Zootec. 37:287-298.

Raabo, E., and T. C. Terkildsen. 1960. On the enzymatic determination of blood glucose. Scand. J. Clin. Lab. Invest. 12:402-407.

Rabelo, E., R. L. Rezende, S. J. Bertics, and R. R. Grummer. 2003 Effects of transition diets varying in dietary energy density on lactation performance and ruminal parameters of dairy cows. J. Dairy Sci. 86:916-925.

Rabelo, E., R. L. Rezende, S. J. Bertics, and R. R. Grummer. 2005. Effects of pre- and postfresh transition diets varying in dietary energy density on metabolic status of periparturient dairy cows. J. Dairy Sci. 88:4375-4383.

Roche, J. R. 2007. Milk production responses to pre- and postcalving dry matter intake in grazing dairy cows. Livest. Sci. 110:12-24.

Rukkwamsuk, T., M. J. H. Geelen, T. A. M. Kruip, and T. Wensing. 2000. Interrelation of fatty acid composition in adipose tissue, serum, and liver of dairy cows during the development of fatty liver postpartum. J. Dairy Sci. 83:52-59.

SAS Institute. 2002. User's Guide. Statistics. Version 9. SAS Institute Inc., Cary, NC.

Sharma, B. K., M. J. Vandehaar, and N. K. Ames. 1994. Expression of insulin-like growth factor-I in cows at different stages of lactation and in late lactation cows treated with somatotropin. J. Dairy Sci. $77: 2232-2241$

Siemens, B. J., and J. K. Daun. 2005. Determination of the fatty acid composition of canola, flax, and solin by near-infrared spectroscopy. J. Am. Oil Chem. Soc. 82:153-157.

Smet, K., K. Raes, J. De Block, L. Herman, K. Dewettinck, and K. Coudijzer. 2008. A change in antioxidative capacity as a measure of onset to oxidation in pasteurized milk. Int. Dairy J. 18:520-530.

Stein, D. T., B. E. Stevenson, M. W. Chester, M. Basit, M. B. Daniels, S. D. Turley, and J. D. McGarry. 1997. The insulinotropic potency of fatty acids is influenced profoundly by their chain length and degree of saturation. J. Clin. Invest. 100:398-403.

Van Den Top, A. M., M. J. H. Geelen, T. Wensing, G. H. Wentink, A. T. V. Klooster, and A. C. Beynen. 1996. Higher postpartum hepatic triacylglycerol concentrations in dairy cows with free rather than restricted access to feed during the dry period are associated with lower activities of hepatic glycerolphosphate acyltransferase. J. Nutr. 126:76-85.

Van Soest, P. J., J. B. Robertson, and B. A. Lewis. 1991. Methods for dietary fiber, neutral detergent fiber and non-starch polysaccharide in relation to animal nutrition. J. Dairy Sci. 74:3583-3597.

Vazquez-Añon, M., S. Bertics, M. Luck, R. R. Grummer, and J. Pinheiro. 1994. Peripartum liver triglyceride and plasma metabolites in dairy cows. J. Dairy Sci. 77:1521-1528.

Ward, A. T., K. M. Wittenberg, and R. Przybylski. 2002. Bovine milk fatty acid profiles produced by feeding diets containing solin, flax and canola. J. Dairy Sci. 85:1191-1196.

Williamson, D. H., and J. Mellanby. 1974. D-(-)-3-Hydroxybutyrate. Pages 1836-1839 in Methods of Enzymatic Analysis. Vol. IV, 2nd ed. H. U. Bergmeyer, ed. Verlag Chemie, Academic Press, New York, NY

Wullepit, N., K. Raes, B. Beerda, R. F. Veerkamp, D. Fremaut, and S. De Smet. 2009. Influence of management and genetic merit for milk yield on the oxidative status of plasma in heifers. Livest. Sci. $123: 276-282$.

Zarban, A., F. Taheri, T. Chahkandi, G. Sharifzadeh, and M. Khorashadizadeh. 2009. Antioxidant and radical scavenging activity of human colostrum, transitional and mature milk. J. Clin. Biochem. Nutr. 45:150-154. 